\title{
Model Elemen Hingga Non Linier Untuk Karakterisasi Panel Dinding Bata Pengisi Terhadap Gaya Lateral Siklik
}

\author{
B. Budiono ${ }^{1} \&$ Herwani $^{2}$ \\ ${ }^{(1)}$ Departemen Teknik Sipil Institut Teknologi Bandung, Bandung \\ ${ }^{(2)}$ JurusanTeknik Sipil Universitas Tanjungpura, Pontianak
}

\begin{abstract}
Sari. Pasangan bata sebagai dinding pengisi antara kolom, pada tingkat pembebanan horisontal tertentu, dapat menahan beban horisontal tersebut seperti dinding geser. Dengan adanya perubahan sifat struktur ini maka dinding bata akan merubah kekakuan dan kekuatan struktur. Bila kontribusi dari pasangan bata diabaikan maka hal tersebut akan menyebabkan konsep dan perencanaan struktur tersebut menjadi kurang tepat. Penelitian ini menyajikan suatu model matematika hubungan tegangan vs. regangan uniaksial dan envelope keruntuhan elemen dinding bata pengisi yang diharapkan dapat digunakan untuk menganalisis perilaku struktur terhadap gaya luar, terutama beban siklik. Pemodelan dilakukan dengan asumsi bahwa pengaruh dinding pasangan bata sebagai dinding pengisi diperhitungkan dalam analisis dan material bata yang digunakan mempunyai sifat kuat tekan yang dominan. Analisis dilakukan menggunakan metode elemen hingga diskrit non-linier. Elemen hingga dengan model isoparametrik delapan nodal, dikembangkan untuk beton dan pasangan bata. Tulangan baja dan elemen penghubung dimodelkan sebagai elemen hingga untuk rangka batang dengan tiga nodal. Variabel yang dipelajari dalam analisis adalah energi disipasi dan penurunan kekakuan. Dalam banyak hal, model memberikan hasil yang memuaskan. Meskipun demikian, beberapa perbaikan perlu dipertimbangkan terutama pada model elemen penghubung.
\end{abstract}

Kata Kunci: Hubungan tegangan-regangan; envelope keruntuhan; elemen beton; elemen bata; elemen penghubung; elemen rangka batang; pembebanan siklik; elemen isoparametrik; energi disipasi; penurunan kekakuan.

\section{The Non Linear Finite Element Model for Characterization of Brick Masonry Infill Wall under Cyclic Lateral Forces}

\begin{abstract}
Brick masonries as the infill walls between columns, for some degree of horizontal loading, are capable of resisting the horizontal load as shear walls. The different behavior of the structure due to the existence of the brick masonries in this case will change the stiffness as well as the strength of the structure. Ignoring this contribution of the brick masonries develops a misleading concept and design for the structure. In this study, a mathematical model representing the relationship between uniaxial stress vs. strain and the failure envelope of the infill brick wall masonry is developed. The implementation of the model is expected to be capable for analyzing the
\end{abstract}


behavior of the structures subjected to external load in particular under cyclic loading. The model assumes that the contribution of the infill walls are taken into account for the analysis and the brick material used is considered as a compression dominated material. Analysis was carried out using non-linear discrete finite element method. Eight nodal isoparametric elements are developed representing concrete and brick masonry elements. Steel reinforcement and linkage elements are modeled as three nodal plane truss element. The variables studied in the analysis are degree of energy dissipation and stiffness degradation. The result showed that the model gives satisfactory results. However, some improvement needs to be considered in the linkage element model.

Keywords: Stress vs. strain relationship; failure envelope; concrete element; brick element; linkage element; truss element; cyclic loading; isoparametric element; dissipation energy; stiffness degradation.

\section{Daftar Notasi}

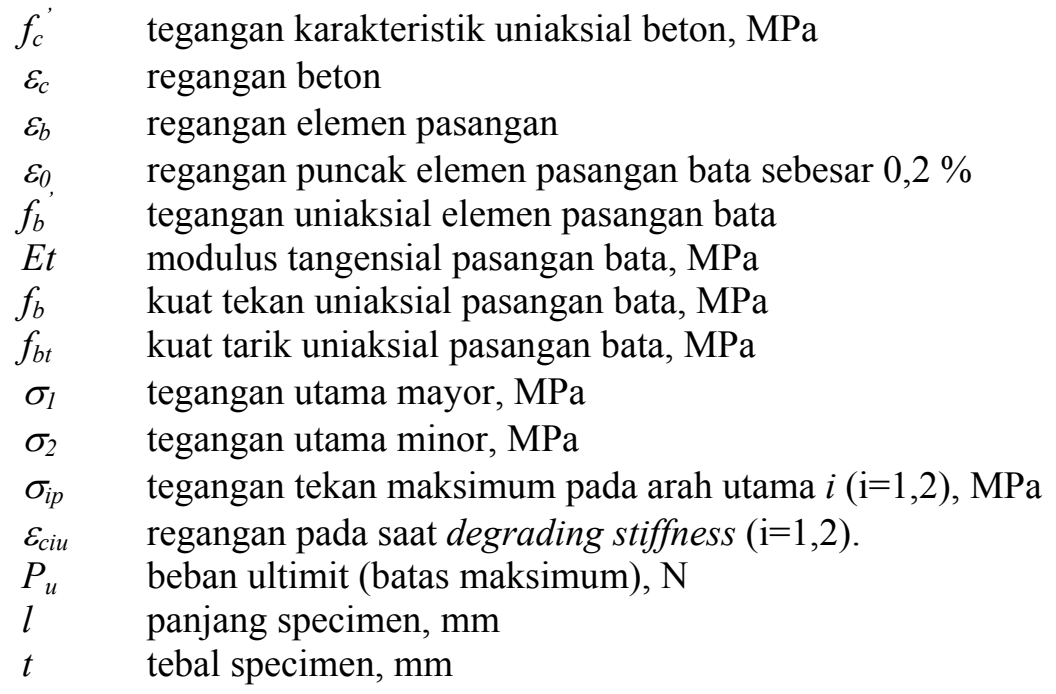

\section{$1 \quad$ Pendahuluan}

Dalam disain struktur seperti portal para rekayasawan tidak memperhitungkan dinding pasangan bata sebagai komponen struktural. Dinding bata diasumsikan sebagai beban gravitasi yang bekerja pada balok. Meskipun demikian pada tingkat pembebanan horisontal tertentu, pasangan bata sebagai dinding pengisi antara kolom dapat menahan beban seperti dinding geser. Perubahan sifat ini dengan adanya dinding bata akan merubah kekakuan dan kekuatan struktur. Bila kontribusi dari pasangan bata diabaikan maka hal tersebut akan menyebabkan konsep dan perencanaan tersebut menjadi kurang tepat. 
Sebuah panel yang terbuat dari pasangan dan terletak pada rangka beton atau baja disebut dinding pengisi ${ }^{[3]}$. Pasangan ini dapat berupa material bata atau batako yang dihubungkan dengan sambungan mortar. Selain itu diantara pasangan dinding pengisi dan rangka beton bertulang yang berada disekitarnya dihubungkan oleh elemen linkage. Umumnya elemen ini berupa shear connector untuk memberikan kekakuan dan kekuatan pada rangka portalnya. Penambahan shear connector pada portal yang berisi dinding memberikan pengaruh yang cukup besar terhadap model keruntuhan dan peningkatan kekuatan portal tersebut ${ }^{[12]}$.

Analisis non-linier struktur yang dibuat dari material getas seperti elemen pasangan dan beton, sulit dilakukan karena respon dari masing-masing material sangat beragam dan tidak stabil ${ }^{[1,5]}$. Demikian juga sistem struktur portal dengan dinding pengisi yang terdiri dari rangka beton bertulang dan pasangan dinding pengisi yang diharapkan mampu memikul beban secara bersamaan.

Untuk mengetahui perilaku struktural dinding pengisi apabila dikenai beban siklik maupun monotonik dibutuhkan analisis karakteristik dari masing-masing elemen pembentuknya terutama hubungan tegangan-regangan. Program RECAP yang dikembangkan oleh Budiono, et.al. ${ }^{[1]}$, memfasilitasi perilaku siklik non-linier baik material beton maupun baja tulangan. Berikut ini akan ditinjau karakteristik material yang digunakan untuk elemen pasangan dinding pengisi.

\section{Hubungan Tegangan-Regangan Pasangan Dinding Bata Pengisi}

Hubungan tegangan-regangan elemen pasangan mempunyai perilaku yang sama dengan beton namun kuat tekannya lebih rendah (Gambar 1). Secara keseluruhan sifat-sifat mekanis pasangan relatif lebih rendah bila dibandingkan dengan beton. Misalnya modulus elastisitas $E_{m}=1000 f_{c}^{\prime}$ untuk pasangan dari beton dan $E_{m}=750 f_{b}^{\prime}$ untuk pasangan dari bata merah ${ }^{[10]}$.

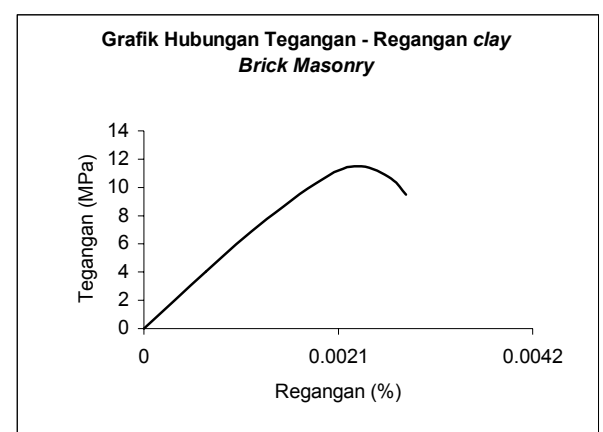

Gambar 1 Kurva hubungan teganganregangan tekan aksial clay brick masonry P.A Hidalgo and C. Luders ${ }^{[6]}$.

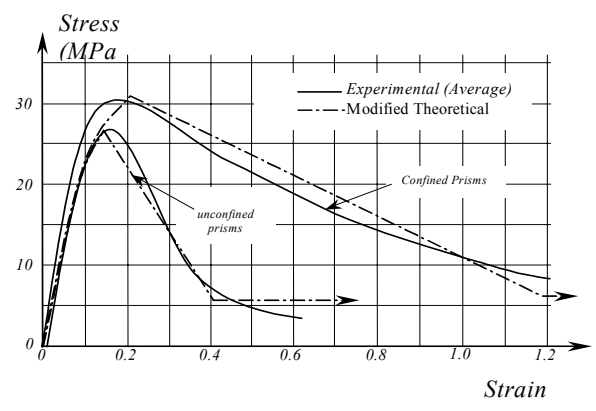

Gambar 2 Kurva tegangan-regangan tekan concrete masonry ${ }^{[10]}$. 
Penambahan kekangan pada dinding pengisi akan menyebabkan peningkatan kekuatan dan daktilitasnya. Hal ini dapat dilihat pada Gambar 2.

\subsection{Model Matematis Tegangan vs Regangan Tekan Pasangan Sebelum Puncak Tegangan Tekan}

Berdasarkan Gambar 1 akan diturunkan model matematika tegangan vs. regangan tekan pasangan bata sebelum puncak tegangan tekan pasangan dilampaui. Model yang dikembangkan mengikuti konsep dari persamaan kekuatan tekan beton uniaksial dengan model Hognestad ${ }^{[9],[12],[13]}$.

Dari curve fitting hasil penelitian eksperimental ${ }^{[6]}$ didapatkan persamaan tegangan vs regangan pasangan bata sebagai berikut:

$$
f_{b}=f_{b}^{\prime}\left[1.28 \frac{\varepsilon_{b}}{\varepsilon_{0}}-0.28\left(\frac{\varepsilon_{b}}{\varepsilon_{0}}\right)^{2}\right]
$$

Modulus secant $\left(E_{s i}\right)$ diperoleh dengan membagi persamaan (1) oleh $\varepsilon_{b}$

$$
E_{s i}=\frac{f_{b}^{\prime}}{\varepsilon_{b}}\left[1.28 \frac{\varepsilon_{b}}{\varepsilon_{0}}-0.28\left(\frac{\varepsilon_{b}}{\varepsilon_{0}}\right)^{2}\right]
$$

Sedangkan modulus tangen $\left(E_{T i}\right)$ diperoleh dengan menurunkan pers.(2) terhadap $\varepsilon_{b}$

$$
E_{T i}=f_{b}^{\prime}\left[\frac{1.28}{\varepsilon_{0}}-0.56 \frac{\varepsilon_{b}}{\varepsilon_{0}}\right]
$$

\subsection{Model Matematis Tegangan vs Regangan Tekan Pasangan Pasca Puncak Tegangan Tekan}

Hubungan tegangan-regangan tekan pasangan pasca puncak tegangan tekan dimodelkan mengikuti bentuk seperti yang terlihat pada Gambar 2. Hubungan ini mengikuti model persamaan beton ${ }^{[5],[9]}$ yaitu

$$
f_{b}=f_{b}^{\prime}\left[1-Z\left(\varepsilon_{b}-\varepsilon_{0}\right)\right]
$$

dengan $Z=\frac{\tan \theta}{f_{b}^{\prime}} ; \tan \theta=Z f_{b}^{\prime}$ 
Dari Gambar 2 diambil tegangan minimum $0.25 f_{b}^{\prime}$ didapat $\tan \theta$. Substitusikan nilai tersebut ke pers. (4) diperoleh persamaan kuat tekan pasangan bata pasca puncak kekuatan tekan sebagai berikut

$$
\begin{array}{lll}
f_{b}=f_{b}\left[1-\frac{0.75\left(\varepsilon_{b}-\varepsilon_{0}\right)}{\varepsilon_{0}\left(\gamma_{2}-1\right)}\right] & \text { untuk } & \left|\varepsilon_{0}\right| \leq\left|\varepsilon_{b}\right|<\left|\gamma_{2} \varepsilon_{0}\right| \\
f_{b}=0.25 f_{b}^{\prime} & \text { untuk } & \left|\varepsilon_{b}\right| \geq\left|\gamma_{2} \varepsilon_{b}\right|
\end{array}
$$

Modulus secant

$$
E_{S i}=f_{b} / \varepsilon_{b}
$$

Jika pers. (6) diturunkan terhadap $\varepsilon_{b}$ maka didapat modulus tangen $\left(E_{T i}\right)$

$$
\begin{array}{lll}
E_{1 i}=\frac{0.75 f_{b}}{\varepsilon_{0}\left(\gamma_{2}-1\right)} & \text { untuk } & \left|\varepsilon_{0}\right| \leq\left|\varepsilon_{b}\right|<\left|\gamma_{2} \varepsilon_{0}\right| \\
E_{T i}=0 & \text { untuk } & \left|\varepsilon_{b}\right| \geq\left|\gamma_{2} \varepsilon_{b}\right|
\end{array}
$$

dimana $\gamma_{2}$ adalah konstanta lebih dari satu.

\subsection{Model Matematis Tegangan vs Regangan Tarik Pasangan Sebelum Puncak Tegangan Tarik}

Model matematis tegangan vs regangan tarik pasangan bata sebelum puncak tegangan tarik dilampaui (sebelum pasangan retak) diturunkan dari idealisai bentuk hasil penelitian yang dilakukan oleh Rob van der Pluijm ${ }^{[1]}$ seperti terlihat pada Gambar 3. Pasangan yang mengalami tegangan tarik sebelum retak, digunakan hubungan linier seperti terlihat pada garis $\mathrm{AB}$.

$$
\sigma_{i}=E_{b} \varepsilon_{i} \quad 0 \leq \varepsilon_{i} \leq \varepsilon_{c r}
$$

\subsection{Model Matematis Tegangan vs Regangan Tarik Pasangan Pasca Puncak Tegangan Tarik}

Setelah mengalami keretakan dimana kekuatan tariknya terlampaui digunakan hubungan ${ }^{[1],[4]}$

$$
\sigma_{i}=\Gamma f_{t}^{\prime}
$$

Koefisien gamma didapat dengan menguraikan persamaan tegangan pada garis BC (Gambar 3) atau persamaan pasangan setelah mencapai kuat tariknya. Hubungan tegangan-regangan diubah menjadi rasio tegangan-regangan yaitu $\sigma_{\mathrm{i}} / f_{t}^{\prime}$ dan $\varepsilon_{i} / \varepsilon_{c r}$. Dengan perbandingan segitiga didapat 


$$
\begin{array}{lll}
\Gamma=\alpha_{2}+\frac{\left(1-\alpha_{2}\right)\left(\alpha_{1}-\varepsilon_{i} / \varepsilon_{c r}\right)}{\left(\alpha_{1}-1\right)} \leq 1.0 & \text { untuk } & \varepsilon_{\mathrm{i}}<\alpha_{1} \varepsilon_{\mathrm{cr}} \\
\Gamma=\alpha_{2} \leq 1.0 & \text { untuk } & \varepsilon_{\mathrm{i}} \geq \alpha_{1} \varepsilon_{\mathrm{cr}}
\end{array}
$$

\subsection{Envelope Keruntuhan Pasangan}

Envelope keruntuhan diambil dari bentuk yang diusulkan oleh Nebojsa Mojsilovic and Peter Marti ${ }^{[8]}$ pada blok material dengan mengadopsi kriteria tegangan bidang Coulomb. Bentuk yang diusulkan dapat dilihat pada Gambar 4 ${ }^{[8]}$. Blok keruntuhan di atas juga merupakan perilaku biaksial material. Tegangan puncak pasangan dihitung dengan persamaan yang diturunkan berdasarkan envelope seperti Gambar 4.

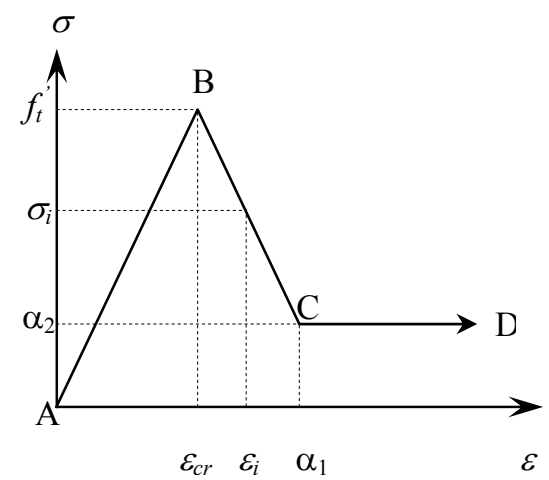

Gambar 3 Permodelan teganganregangan tarik pasangan ${ }^{[11]}$.

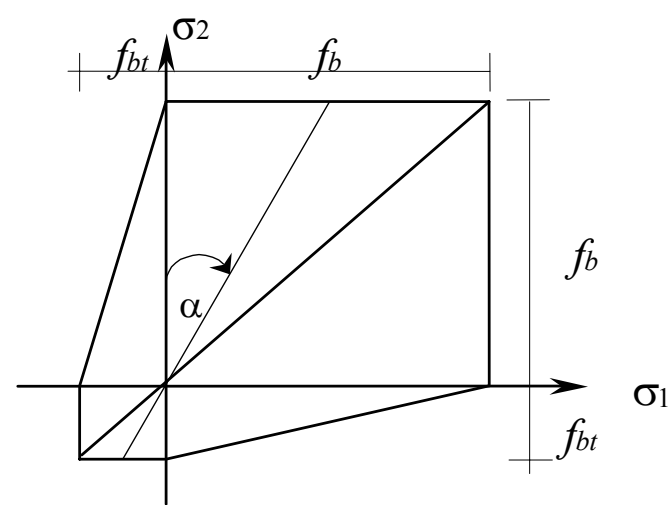

Gambar 4 Kriteria keruntuhan blok material ${ }^{[8]}$

Untuk kekuatan tekan biaksial persamaan ditulis

$\sigma_{2 p}=f_{b}$

$\sigma_{l p}=\alpha f_{b}$

untuk tekan biaksial

Untuk kekuatan tarik biaksial persamaan mengikuti

$\left.\begin{array}{l}\sigma_{2 p}=f_{b t} / \alpha \\ \sigma_{l p}=\alpha \sigma_{2 p}\end{array}\right\}$ untuk tarik biaksial

dimana $\alpha=\sigma_{1} / \sigma_{2}$ berlaku untuk persamaan (14) dan (15).

Elemen pasangan yang mengalami tegangan biaksial tarik-tekan mempunyai hubungan linier. Dari Gambar 4 dapat dilihat bahwa penurunan puncak tegangan tekan utama $\left(\sigma_{2}\right)$ berbanding lurus dengan kenaikan puncak tegangan tarik $\left(\sigma_{I}\right)$. Hubungan diasumsikan mengikuti persamaan garis lurus dengan hubungan antara tegangan tarik dan tekan didefinisikan sebagai $\alpha=\sigma_{1} / \sigma_{2}$, 
sehingga diperoleh hubungan kekuatan biaksial untuk tarik dan tekan adalah sebagai berikut

$$
\left.\begin{array}{l}
\sigma_{2 p}=\frac{f_{b}}{\left\{1+\left(f_{b} / f_{b t}\right) \alpha\right\}} \\
\sigma_{l p}=\alpha \sigma_{2 p}
\end{array}\right\} \text { untuk biaksial tarik-tekan }
$$

Dari envelope keruntuhan didapat tegangan utama puncak mayor maupun minor dengan persamaan yang ada. Regangan yang berhubungan dengan tegangan tersebut dihitung dengan persamaan Crisfield ${ }^{[2]}$.

$$
\begin{array}{lll}
\varepsilon_{i p}=\varepsilon_{0}\left[\frac{3 \sigma_{i b}}{f_{b}^{\prime}}-2\right] & \text { untuk } & \left|\sigma_{i b}\right| \geq\left|f_{b}^{\prime}\right| \\
\varepsilon_{i p}=\varepsilon_{0}\left[0.35\left(\frac{\sigma_{i b}}{f_{b}^{\prime}}\right)+2.25\left(\frac{\sigma_{i b}}{f_{b}^{\prime}}\right)^{2}-1.6\left(\frac{\sigma_{i b}}{f_{b}^{\prime}}\right)^{3}\right] \text { untuk } & \left|\sigma_{i b}\right|<\left|f_{b}^{\prime}\right|
\end{array}
$$

\subsection{Model Pembebanan Siklik Untuk Tegangan vs Regangan Tekan Pasangan}

Hubungan tegangan-regangan tekan pasangan yang dibebani secara siklik menggunakan bentuk seperti yang pada Gambar 5. Untuk elemen biaksial tekan pasangan digunakan konsep regangan uniaksial ekivalen $\left(\varepsilon_{i u}\right)$ Darwin dan Pecknold yang dibahas oleh Budiono, et.al ${ }^{[1]}$. Pada kondisi ini selama unloading modulus secant ditentukan sebagai fungsi dari regangan utama $\left(\varepsilon_{i}\right)$. Bila regangan utama $\varepsilon_{i, \max }(i=1,2)$ pada saat unloading diketahui maka dari hubungan yang ditunjukkan pada Gambar 5 dapat ditentukan regangan uniaksial ekivalen $\varepsilon_{i u, \max }$ dengan formulasi berikut

$$
\begin{aligned}
& \varepsilon_{1 u, \text { max }}=\frac{\sigma_{1, \text { max }}}{E_{1, \text { max }}} \\
& \varepsilon_{1 u, \text { max }}=\left[\frac{1}{\left(1-v^{2}\right)}\left(\varepsilon_{1, \text { max }} E_{1, \text { max }}+v \varepsilon_{2, \text { max }} E_{2, \text { max }}\right)\right] / E_{1, \text { max }} \\
& \varepsilon_{2 u, \text { max }}=\frac{\sigma_{2, \text { max }}}{E_{2, \text { max }}} \\
& \varepsilon_{2 u, \text { max }}=\left[\frac{1}{\left(1-v^{2}\right)}\left(\varepsilon_{2, \text { max }} E_{2, \text { max }}+v \varepsilon_{1, \text { max }} E_{1, \text { max }}\right)\right] / E_{2, \text { max }}
\end{aligned}
$$


Berdasarkan hubungan bilinier bila $E_{i, \max }$ dan $\varepsilon_{I}$ diketahui maka regangan uniaksial ekivalen $\varepsilon_{i u}$ selama unloading ditentukan dengan formulasi berikut

$$
\begin{aligned}
& \varepsilon_{1 u,}=\frac{\sigma_{1}^{*}}{E_{1, \text { max }}}=\left[\frac{1}{\left(1-v^{2}\right)}\left(\varepsilon_{1} E_{1, \text { max }}+v \varepsilon_{2} E_{2, \text { max }}\right)\right] / E_{1, \text { max }} \\
& \varepsilon_{2 u}=\frac{\sigma_{2}^{*}}{E_{2, \text { max }}}=\left[\frac{1}{\left(1-v^{2}\right)}\left(\varepsilon_{2} E_{2, \text { max }}+v \varepsilon_{1} E_{1, \text { max }}\right)\right] / E_{2, \text { max }}
\end{aligned}
$$

Modulus secant selama unloading $\left(E_{i}\right)$ seperti yang pada Gambar 5 ditentukan dengan rumus berikut

$$
E_{i}=\left[\sigma_{i, \max }-\left(\varepsilon_{i u, \max }-\varepsilon_{i u}\right) E_{t}\right] / \varepsilon_{i u}
$$

Pada saat pasangan belum mencapai kekuatan puncak tekannya maka $E_{t}$ sama dengan modulus awal $E_{0}$. Sebaliknya bila pasangan sudah mencapai kekuatan puncak tekannya, dimana $\left|\varepsilon_{i u}\right|>\left|\varepsilon_{0}\right|$ maka $E_{t}$ sama dengan $E_{d}$.

$$
E_{d}=\frac{\sigma_{i, \max }}{\varepsilon_{i u, \max }-\varepsilon_{c i u}}
$$

Nilai regangan $\varepsilon_{c i u}$ dihitung dengan formulasi sebagai berikut

$$
\varepsilon_{c i u}=\varepsilon_{i u, \text { max }}\left(0.15 \varepsilon_{i u, \text { max }} / \varepsilon_{0}+0.1\right)
$$

Untuk pasangan pada kondisi tegangan biaksial tarik-tekan, sebelum retak $E_{1, \max }$ sama dengan $E_{0}$ sedangkan $\varepsilon_{2 u, \max }$ dan $\varepsilon_{2 u}$ dihitung dengan persamaan (20) dan (22), setelah retak terjadi rasio poisson sama dengan nol dan modulus pada arah utama kedua diberikan oleh persamaan

$$
\begin{aligned}
& E_{2}=\left[\sigma_{2, \max }-\left(\varepsilon_{2, \max }-\varepsilon_{2}\right) E_{t}\right] / \varepsilon_{2} \\
& \text { dimana } \quad E_{t}=E_{0} \text { untuk }\left|\varepsilon_{2}\right| \leq\left|\varepsilon_{0}\right| \\
& E_{t}=E_{d} \text { untuk }\left|\varepsilon_{2}\right|>\left|\varepsilon_{0}\right|
\end{aligned}
$$

\subsection{Model Pembebanan Siklik Untuk Tegangan vs Regangan Tarik Pasangan}

Model pembebanan siklik tarik pasangan dibuat seperti yang ditunjukkan Gambar 6. Bila unloading terjadi pada elemen pasangan yang belum retak, modulus secant dan tangen akan sama dengan kekakuan tangen awalnya. Setelah pasangan mengalami keretakan unloading terjadi mengikuti satu garis lurus dengan modulus tangenya adalah $\mathrm{E}_{0}$ sedangkan modulus sekannya 
dihitung dengan persamaan (26). Bila regangan kurang dari $\varepsilon_{t i}$ pada saat unloading sudah sempurna maka tegangan tarik sama dengan nol dan reloading baru akan terjadi apabila regangan lebih besar dari $\varepsilon_{t i}$ dan bertambah secara linier sampai tegangan tarik mencapai envelope kurva monotoniknya.

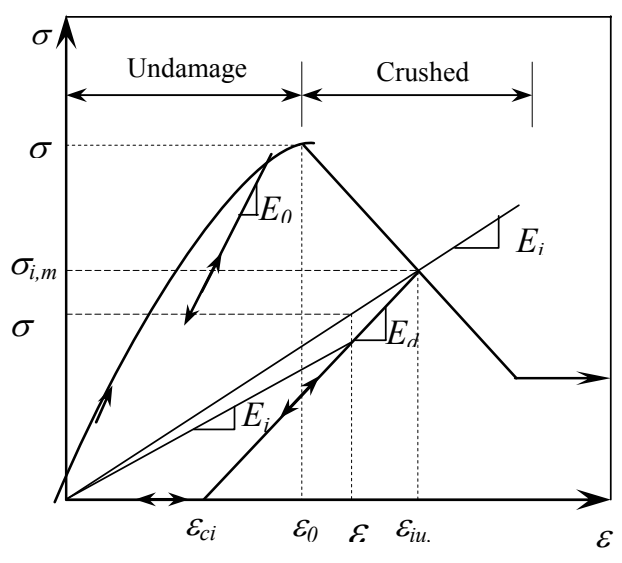

Gambar 5 Perhitungan modulus secant pasangan saat unloading tekan biaksial $^{[1]}$.

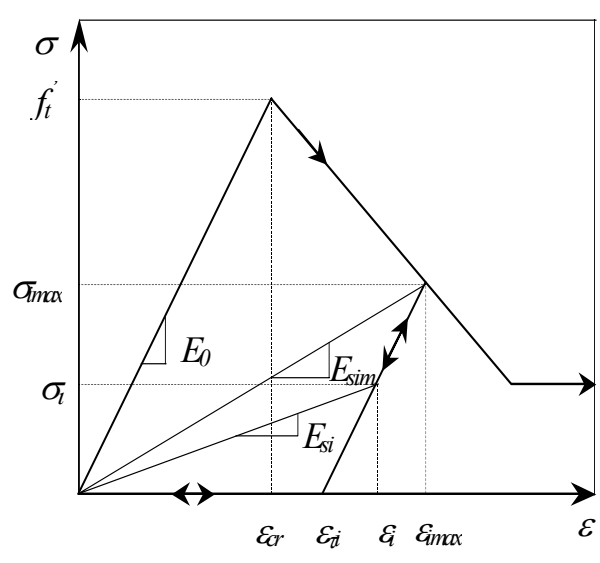

Gambar 6 Perilaku histerik tarikpasangan setelah mengalami keretakan $^{[1]}$.

\section{$3 \quad$ Studi Portal Dengan Dinding Pengisi}

\subsection{Bentuk dan Ukuran Struktur}

Studi ini dilakukan pada struktur dinding solid brick blocks yang terkekang oleh kolom praktis (benda uji Fumitoshi Kumazawa dan Masaaki Ohkubo ${ }^{[7]}$ ). Bentuk dan ukuran struktur dapat dilihat pada Gambar 7.

Sambungan pada arah vertikal dan horisontal pasangan digunakan mortar dan shear connector baja yang berfungsi sebagai elemen linkage. Elemen linkage ini diasumsikan berperilaku seperti baja tulangan dengan model tegangan vs regangan menggunakan hubungan bilinier elastoplastis. Kekuatan leleh baja $f y=240 \mathrm{MPa}$. Diameter nominal tulangan lentur dan sengkang pada kolom maupun balok adalah $10 \mathrm{~mm}$ dan $4 \mathrm{~mm}$ dengan jarak antar sengkang $40 \mathrm{~mm}$. Balok berbentuk persegi berukuran 400x400 mm sedangkan kolom berukuran $115 \times 115 \mathrm{~mm}$. Dengan demikian kekakuan pada elemen balok jauh lebih besar dibanding kolom praktis. Perpindahan pada kedua kolom tersebut diharapkan terjadi secara bersamaan dengan besar yang sama pula. Rincian material disajikan pada Tabel 1. Benda uji ini dinamakan UMC (Unreinforced Masonry under Cyclic Loading). 


\subsection{Pemodelan Elemen Hingga}

Pemodelan elemen hingga baik untuk pasangan bata maupun beton digunakan model elemen hingga bidang ( 2 dimensi) isoparametik dengan delapan titik nodal. Sambungan mortar dan shear connector baja yang menghubungkan tiap unit bata atau batako pada celah antara dinding pasangan dengan portal disekelilingnya dimodelkan elemen linkage sebagai baja tulangan yaitu plane truss dengan tiga titik nodal. Luas tulangan baik tarik maupun geser dalam pemodelan dihitung secara merata untuk setiap luas elemen bidang. Kemudian elemen tersebut dirakit dengan system diskrit yaitu dengan sistem tumpang tindih baik pada sisi elemen beton maupun bata pada titik nodal.

Kondisi batas diasumsikan sendi yang tidak membolehkan pergerakan baik pada arah horizontal maupun vertikal, untuk dasar balok. Sedangkan untuk balok atas dapat bergerak bebas. Beban vertikal diberikan secara konstan dengan besar tertentu, sedangkan untuk besar beban horizontal diberikan bervariasi. Untuk mencegah kehancuran beton secara prematur akibat pembebanan maka pada bagian yang menerima beban luar dipasang plat baja setebal $10 \mathrm{~mm}$. Pemodelan elemen hingga untuk semua komponen struktur dapat dilihat pada Gambar 8.

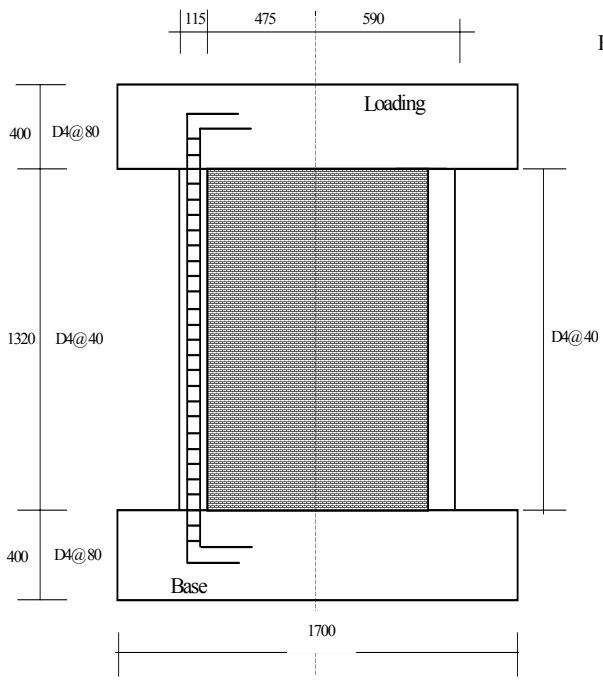

Gambar 7 Struktur dinding benda uji Ohkubo ${ }^{[7]}$.

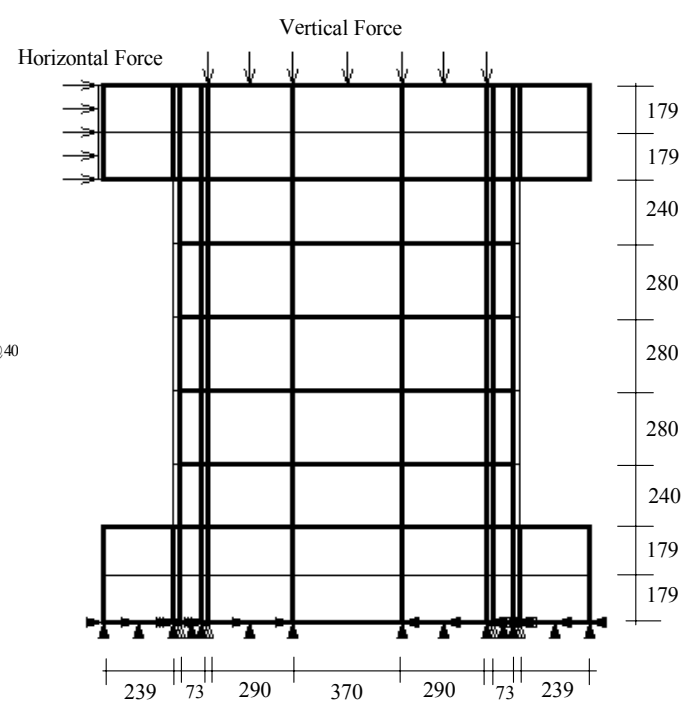

Gambar 8 Pembagian elemen-elemen kecil (meshing) dinding pasangan. 


\subsection{Sifat Bahan (Material Properties)}

Material properties dalam studi ini didapat dari data eksperimental yang ditunjukkan pada Tabel 1. Kuat tarik pasangan diperoleh dengan formulasi pendekatan sebagai berikut ${ }^{[4]}$

$$
\sigma_{t u}=0.52 \frac{P_{u}}{l . t}
$$

Besar $P_{u}$ didapat dari data eksperimen untuk spesimen yang sama ${ }^{[9]}$.

a) Beton (silinder : $\mathrm{D}=100 \mathrm{~mm}, \mathrm{~h}=200 \mathrm{~mm}$ )

\begin{tabular}{|c|c|c|c|c|}
\hline $\begin{array}{c}\text { Tekan } \\
\text { Maksimum, } \mathrm{f}_{\mathrm{c}} \\
\left(\mathrm{N} / \mathrm{mm}^{2}\right)\end{array}$ & $\begin{array}{c}\text { Young's } \\
\text { Modulus } \\
\left(\mathrm{N} / \mathrm{mm}^{2}\right)\end{array}$ & $\begin{array}{c}\text { Regangan } \\
\text { pada } \mathrm{f}_{\mathrm{c}}\end{array}$ & $\begin{array}{c}\text { Nilai } \\
\text { Poisson }\end{array}$ & $\begin{array}{c}\text { Tarik } \\
\text { Maksimum } \\
\left(\mathrm{N} / \mathrm{mm}^{2}\right)\end{array}$ \\
\hline 29.8 & $1.90 \times 10^{4}$ & $2.739 \times 10^{-6}$ & 0.186 & 2.58 \\
\hline
\end{tabular}

b) Bata (kubus : $\mathrm{D}=65 \mathrm{~mm})$

\begin{tabular}{|c|c|}
\hline $\begin{array}{c}\text { Specific Gravity } \\
\left(\mathrm{g} / \mathrm{cm}^{3}\right)\end{array}$ & $\begin{array}{c}\text { Tekan Maksimum } \\
\left(\mathrm{N} / \mathrm{mm}^{2}\right)\end{array}$ \\
\hline 1.55 & 13.4 \\
\hline
\end{tabular}

c) Baja Tulangan

\begin{tabular}{|c|c|c|c|c|}
\hline $\begin{array}{c}\text { Jenis } \\
\text { Tulangan }\end{array}$ & $\begin{array}{c}\text { Tegangan } \\
\text { Leleh } \\
\left(\mathrm{N} / \mathrm{mm}^{2}\right)\end{array}$ & $\begin{array}{c}\text { Tarik } \\
\text { Max. } \\
\left(\mathrm{N} / \mathrm{mm}^{2}\right)\end{array}$ & $\begin{array}{c}\text { Young's } \\
\text { Modulus } \\
\left(\mathrm{N} / \mathrm{mm}^{2}\right)\end{array}$ & $\begin{array}{c}\text { Regangan tarik } \\
\text { Maksimum }\end{array}$ \\
\hline D10 & 333.8 & 444.0 & $1.83 \times 10^{5}$ & $1.840 \times 10^{-6}$ \\
\hline D4 & 317.5 & 452.9 & $2.22 \times 10^{5}$ & $1.440 \times 10^{-6}$ \\
\hline
\end{tabular}

Tabel 1 Material properties spesimen ${ }^{[7]}$.

\subsection{Analisis Portal dengan Dinding Pengisi}

Analisis dilakukan dengan bantuan program $\operatorname{RECAP}^{[1]}$ yang dimodifikasi menggunakan karakteristik pasangan dan persamaan di atas. Untuk melihat perilaku struktur maka sistem pembebanan pada studi ini dilakukan secara monotonik dan siklik. Kemudian hasil yang diperoleh dari model dibandingkan dengan hasil eksperimental terutama kesesuaian bentuk hubungan bebanperpindahan, kekakuan serta disipasi energi yang diserap oleh struktur. Disipasi energi dapat didefinisikan sebagai luas daerah yang dibatasi oleh kurva tertutup histeresis beban perpindahan. Hasil analisis pembebanan monotonik yang 
disajikan dalam bentuk grafik hubungan beban perpindahan dapat dilihat pada Gambar 9. Grafik umm (Unreinforced Masonry under Monotonic Loading) menunjukkan hasil analisis model sedangkan grafik okb (Ohkubo) adalah hasil analisis model numerik yang dilakukan Kumazawa dan Ohkubo ${ }^{[7]}$. Dari gambar tersebut, hasil yang diperoleh sudah cukup baik dengan penyimpangan sekitar $5 \%$. Nilai ini diambil dari luasan yang terbentuk oleh masing-masing kurva.

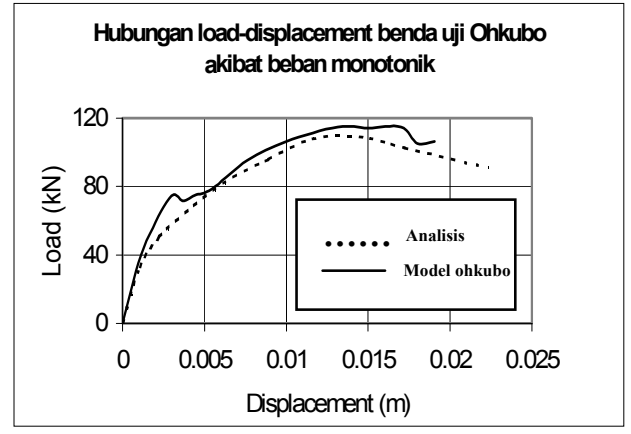

Gambar 9 Hubungan load vs. displacement akibat beban monotonik.

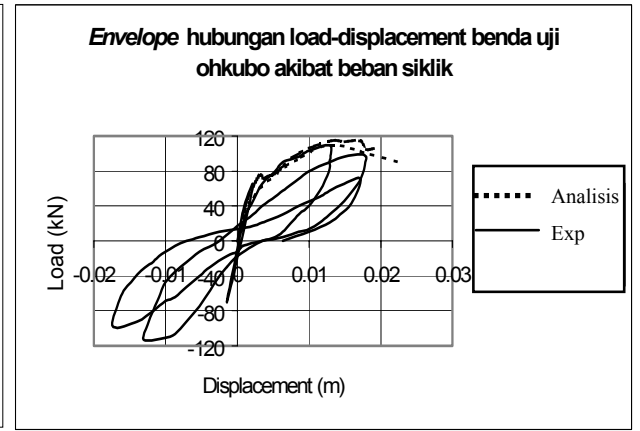

Gambar 10 Envelope hubungan loaddisplacement akibat beban siklik.

Kumazawa dan Ohkubo ${ }^{[7]}$ memperoleh hasil bahwa kurva envelope akibat beban monotonik tidak mengalami perubahan yang signifikan bila dibandingkan dengan kurva envelope pada hubungan beban perpindahan akibat beban siklik. Verifikasi model analitikal dalam studi ini terhadap hasil penelitian Kumazawa dan Ohkubo ${ }^{[7]}$ memberikan prediksi yang sama, seperti yang ditunjukkan pada Gambar 10.

Verifikasi model juga dilakukan untuk beban siklik dengan riwayat pembebanan dilakukan pada siklus elastik dan tiga siklus inelastik sampai pembebanan maksimum. Riwayat pembebanan yang dilakukan pada model dapat dilihat pada Gambar 11. Dari hubungan beban perpindahan akibat beban siklik akan ditinjau beberapa parameter menyangkut kekakuan dan disipasi energi yang menunjukkan perilaku dinding selama menerima beban.

Dari Gambar 12 terlihat bahwa perilaku spesimen berbeda bila dibandingkan dengan hasil eksperimen, meskipun perbedaannya tidak signifikan. Perbedaan tersebut disebabkan pasangan yang tersusun dari bata mengalami slip pada interface antara bata dan mortar. Adanya elemen linkage (penghubung) antara pasangan dengan rangka beton bertulang baik dalam arah horizontal maupun vertikal yang menyebabkan terjadi mekanisme interlocking yang lebih besar. Hal ini menyebabkan energi disipasi model sedikit lebih kecil. Oleh karena itu dalam pemodelan kedua elemen penghubung tersebut masih perlu disempurnakan. 


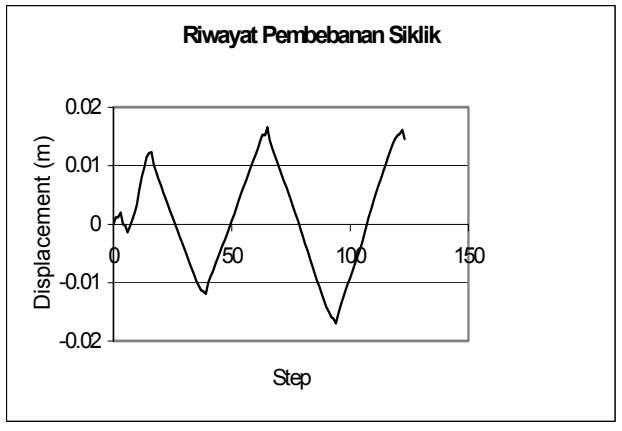

Gambar 11 Riwayat pembebanan siklik.

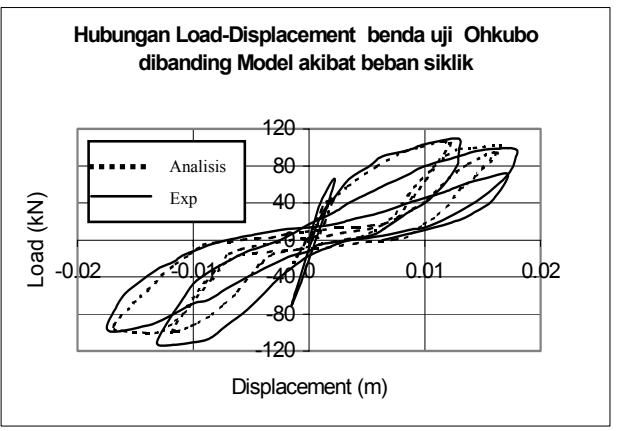

Gambar 12 Hubungan beban perpindahan model dibanding eksperimen akibat beban siklik.

Pada benda uji yang digunakan Ohkubo ${ }^{[7]}$, tegangan geser ditargetkan sebesar $1.36 \mathrm{~N} / \mathrm{mm}^{2}$ dengan penambahan gaya vertikal. Dalam pemodelan, gaya vertikal diberikan secara konstan dengan nilai pendekatan diambil dari tegangan geser dibagi luas bidang gesernya.

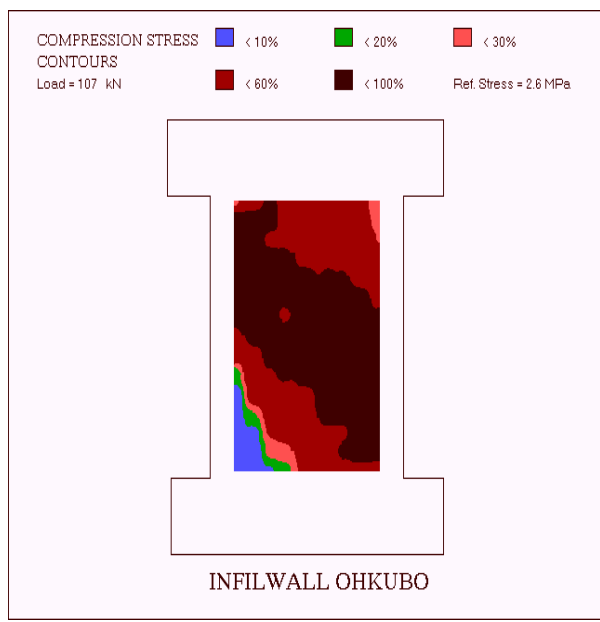

Gambar 13 Kontur tegangan pada siklus II arah positif.

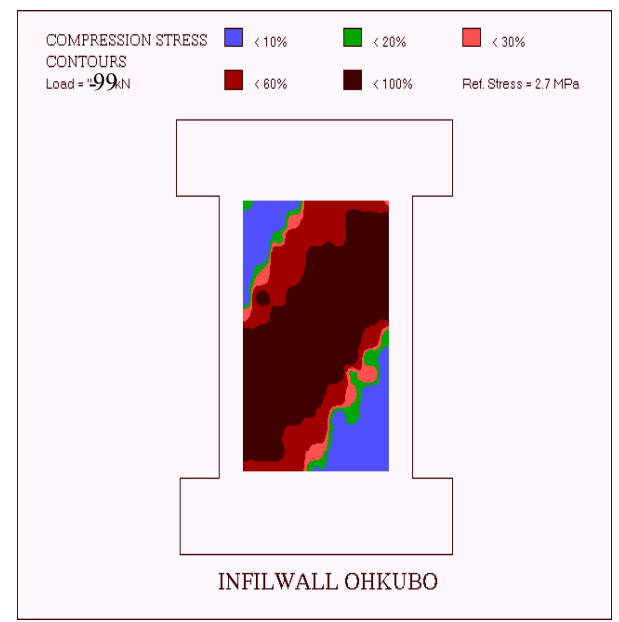

Gambar 14 Kontur tegangan pada siklus II arah negatif.

Pada siklus pertama diawal pembebanan elemen pasangan dan beton masih bekerja secara monolit dalam memikul beban yang diaplikasikan namun pada siklus berikutnya seiring dengan terjadi keretakan dinding maka elemen pasangan bekerja secara diagonal yang berarti setiap Gauss point pada diagonal tersebut hanya mengalami gaya tekan. Hal ini akan menyebabkan tegangan yang besar terkonsentrasi pada strut diagonal. 
Gambar 13 dan Gambar 14 menunjukkan kontur tegangan pada siklus kedua untuk pembebanan positif dan negatif. Sedangkan Gambar 15 dan Gambar 16 menunjukkan vektor tegangan yang bekerja pada titik Gauss point baik tegangan tarik maupun tekan disaat spesimen mengalami pembebanan positif dan negatif. Dari gambar tersebut terlihat bahwa elemen pasangan mengalami strut diagonal tekan dominan.

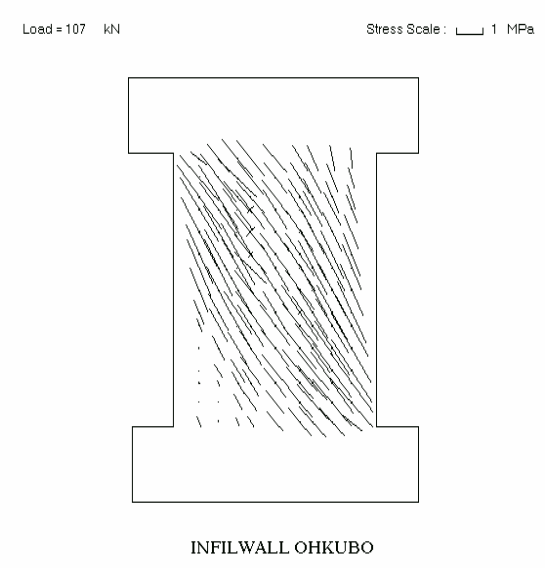

Gambar 15 Vektor tegangan pada Gauss point pada siklus II arah positif.

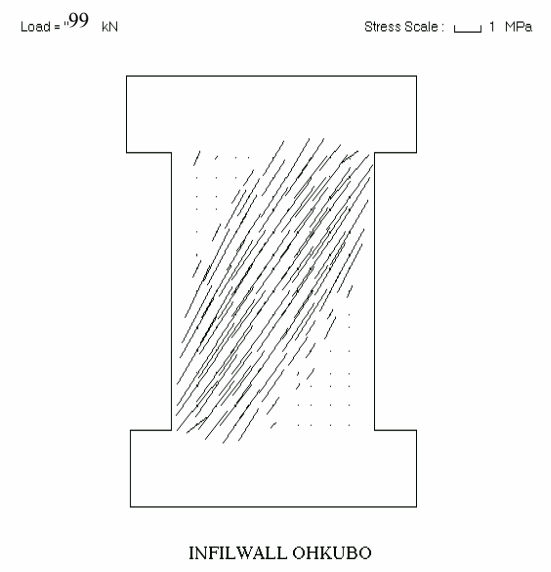

Gambar 16 Vektor tegangan pada Gauss point pada siklus II arah negatif.

\subsection{Analisis Disipasi Energi dan Kekakuan Struktur}

Penurunan kekakuan spesimen akibat beban lateral siklik terutama disebabkan karena terjadi pembukaan retak pada beban siklik sebelumnya tidak sanggup menutup kembali pada beban siklik berikut akibat leleh tulangan dan remuknya elemen pasangan (akibat tegangan tekan puncaknya dilampaui), namun secara keseluruhan sistem belum mengalami keruntuhan. Degradasi baik kekuatan

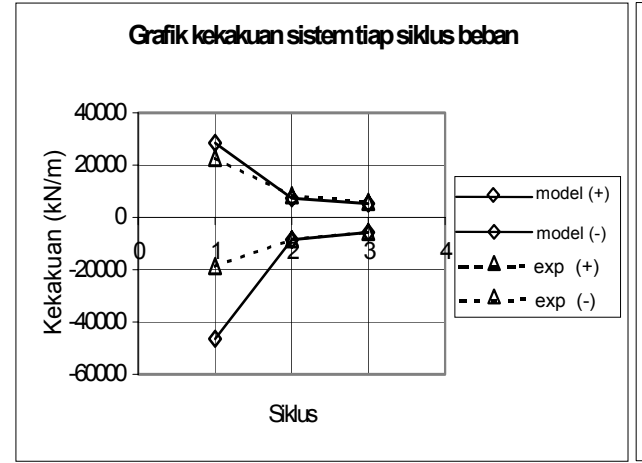

Gambar 17 Grafik kekakuan antara model dan hasil eksperimental ${ }^{[7]}$.

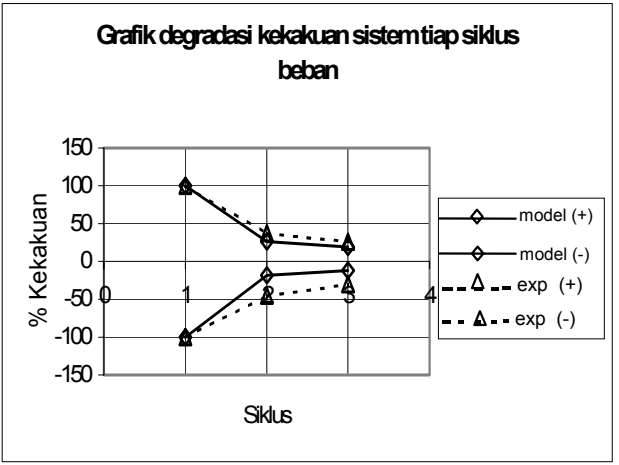

Gambar 18 Grafik degradasi kekakuan antara model dan hasil eksperimental ${ }^{[7]}$. 
maupun kekakuan akibat beban lateral siklik, antara model dibandingkan dengan hasil ekperimental dapat dilihat pada Gambar 17 dan Gambar 18. Kemudian penyimpangan antara kekakuan yang didapat menggunakan model dibandingkan dengan hasil eksperimental yang disajikan dalam pada Tabel 2 untuk arah positif sedangkan Tabel 3 untuk arah negatif.

\begin{tabular}{|c|c|c|c|}
\hline \multirow{2}{*}{ Siklus } & \multicolumn{3}{|c|}{ Kekakuan } \\
\cline { 2 - 4 } & $\begin{array}{c}\text { Eksperimen } \\
\text { (a) }\end{array}$ & Model (b) & $\begin{array}{c}\% \text { selisih (s) } \\
\mathrm{s}=\mid \begin{array}{c}\mathrm{a} \text {-b } \mid / \mathrm{a} \mathrm{x} \\
100 \%\end{array}\end{array}$ \\
\hline 1 & 28509.984 & 22794.953 & 20.046 \\
\hline 2 & 7466.424 & 8502.447 & 13.876 \\
\hline 3 & 5385.694 & 6055.556 & 12.438 \\
\hline
\end{tabular}

\begin{tabular}{|c|c|c|c|}
\hline \multirow{2}{*}{ Siklus } & \multicolumn{3}{|c|}{ Kekakuan } \\
\cline { 2 - 4 } & $\begin{array}{c}\text { Eksperimen } \\
\text { (a) }\end{array}$ & Model (b) & $\begin{array}{c}\% \text { selisih (s) } \\
\mathrm{s}=\mid \mathrm{a} \text {-b } / / \mathrm{a} x \\
100 \%\end{array}$ \\
\hline 1 & -46360.905 & -18574.005 & 59.936 \\
\hline 2 & -8585.765 & -8380.924 & 2.386 \\
\hline 3 & -5654.171 & -5542.376 & 1.977 \\
\hline
\end{tabular}

Tabel 2 Kekakuan spesimen arah positif. Tabel 3 Kekakuan spesimen arah negatif.

Dari Tabel 2 dan Tabel 3 di atas terlihat antara hasil model analitikal dan hasil ekperimental terdapat penyimpangan yang cukup signifikan terutama pada siklus pertama arah negatif. Hal ini disebabkan oleh terjadi keretakan elemen pasangan disaat siklus pertama dibebani arah positif sampai perpindahan maksimum tercapai. Setelah itu beban berbalik arah yang menyebabkan pasangan remuk pada kondisi deformasi yang hampir sama tetapi beban maksimum yang lebih rendah akibat slip pada tulangan. Kondisi ini tidak dapat sepenuhnya dideteksi oleh model analitikal.

Besarnya energi yang diserap model akan dibandingkan dengan ekperimen. Tabel 4 menyajikan energi disipasi yang diserap struktur hasil eksperimental dan model sedangkan Tabel 5 menunjukkan energi kumulatifnya. Plot energi tiap siklus dapat dilihat pada Gambar 19 sedangkan energi kumulatifnya ditunjukkan oleh Gambar 20.

\begin{tabular}{|c|c|c|c|}
\hline \multirow{2}{*}{ Siklus } & \multicolumn{3}{|c|}{ Energi Disipasi kNm } \\
\cline { 2 - 4 } & $\begin{array}{c}\text { Eksperimen } \\
\text { (a) }\end{array}$ & $\begin{array}{c}\text { Model } \\
\text { (b) }\end{array}$ & $\begin{array}{c}\% \text { selisih (s) } \\
\mathrm{s}=|\mathrm{a}-\mathrm{b}| / \mathrm{a} \mathrm{x} \\
100 \%\end{array}$ \\
\hline 1 & 0.050 & 0.006 & 87.417 \\
\hline 2 & 1.326 & 0.851 & 35.822 \\
\hline 3 & 1.503 & 0.877 & 41.687 \\
\hline
\end{tabular}

Tabel 4 Energi disipasi tiap siklus.

\begin{tabular}{|c|c|c|c|}
\hline \multirow{2}{*}{ Siklus } & \multicolumn{3}{|c|}{ Energi Disipasi Kumulatif kNm } \\
\cline { 2 - 4 } & $\begin{array}{c}\text { Eksperimen } \\
\text { (a) }\end{array}$ & Model (b) & $\begin{array}{c}\% \text { selisih (s) } \\
\mathrm{s}=|\mathrm{a}-\mathrm{b}| / \mathrm{a} \text { x } \\
100 \%\end{array}$ \\
\hline 1 & 0.050 & 0.006 & 87.417 \\
\hline 2 & 1.376 & 0.858 & 37.685 \\
\hline 3 & 2.879 & 1.734 & 39.774 \\
\hline
\end{tabular}

Tabel 5 Energi disipasi kumulatif tiap siklus.

Analogi dengan kekakuan, pada energi disipasi antara eksperimen dibanding model terdapat penyimpangan yang cukup signifikan pada tiap siklusnya. Hal 
ini disebabkan oleh adanya perilaku pinching (deformasi yang relatif besar dengan beban kecil pada siklus loading) pada model yang sekaligus menunjukkan bahwa model belum sempurna. Pinching diakibatkan oleh slip pada elemen penghubung dengan material pasangan bata dan beton disekitarnya, yang diabaikan dalam pemodelan. Dengan demikian, pemodelan elemen penghubung antara pasangan dinding pengisi dengan rangka beton yang ada di sekitarnya masih perlu disempurnakan.

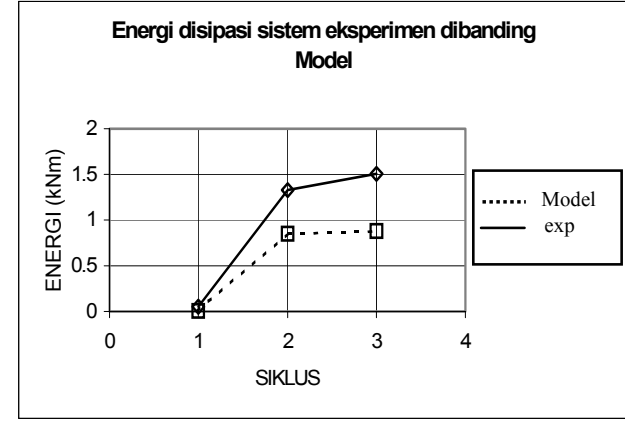

Gambar 19 Energi disipasi kumulatif tiap siklus.

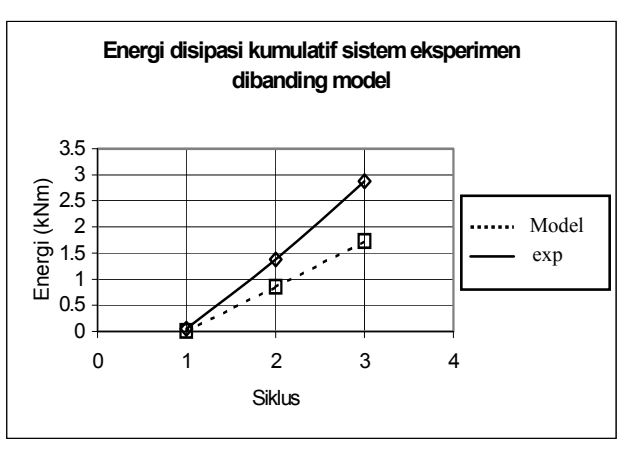

Gambar 20 Energi disipasi tiap siklus.

\section{$4 \quad$ Kesimpulan dan Saran}

Dari hasil studi kasus dan analisis maka dapat diambil beberapa kesimpulan sebagai berikut:

1. Verifikasi hasil antara model analitikal dan hasil eksperimental untuk hubungan beban perpindahan akibat beban monotonik, menunjukkan nilai yang baik. Model analitikal lebih baik dari model terdahulu yang dikembangkan Kumazawa dan Ohkubo ${ }^{[7]}$. Perbedaan energi disipasi yang terbentuk oleh kurva monotonik model dibandingkan dengan hasil eksperimental mempunyai selisih yang lebih kecil dibandingkan dengan model terdahulu.

2. Dari grafik hubungan beban perpindahan akibat beban siklik pada benda uji Ohkubo, dapat diketahui kekakuan dan disipasi energi struktur. Bila dibandingkan hasil eksperimen Ohkubo dan model analitikal, terdapat penyimpangan yang cukup signifikan. Hal ini disebabkan oleh terjadinya slip baik pada tulangan baja maupun elemen linkage yang tidak dapat dideteksi oleh model analitikal.

3. Persamaan dan karakteristik material yang dikembangkan dalam studi analisis dibawah beban siklik perlu disempurnakan untuk pemodelan elemen linkage, dengan memperhitungkan pengaruh slip pada elemen tersebut. 


\section{Daftar Pustaka}

1. Budiono, B., Gibert, R. I. \& Foster, S. J., Non-Linier Finite Element Model for Partially Prestressed Concrete under Cyclic Load, The University of New South Wales, Sydney, Australia (1994).

2. Crisfield, M. A., Non-Linear Finite Element Analysis of Solids and Structures Volume 1, John Wiley \& Sons, England (1991).

3. FEMA, NEHRP Guidelines for the Seismic Rehabilitation of Buildings, Washington, D. C. (1997).

4. Focardi, F. \& Manzini, E., Diagonal Tension Tests on Reinforced and Non-Reinforced Brick Panels, Eighth World Conference on Earthquake Engineering Volume VI, San Francisco (1984).

5. Galanti, F. M. B., Tom Scarpas, \& Vrouwenvelder, A. C. W., Finite Element Techniques for Simulation of Infilled Reinforced Concrete Buildings Under Earthquake Loading, 12WCEE (2000).

6. Hidalgo, P. A. \& Luders, C., Earthquake-Resistant Design of Reinforced Masonry Buildings, Eighth World Conference on Earthquake Engineering Volume VI, San Francisco (1984).

7. Kumazawa, F. \& Ohkubo, M., NonLinier Characteristics of confined Masonry Wall with Lateral Reinforcement in Mortar Joints, 12WCEE (2000).

8. Mojsilovic, N. \& Marti, P., Strength of Masonry Subjected to Combine Actions, ACI Structural Journal (1997).

9. Park, R. \& Paulay, T., Reinforced Concrete Structure, John Wiley \& Sons, New York (1975).

10. Paulay, T. \& Priestley, M. J. N., Seismic Design of Reinforced Concrete and Masonry Buildings, John Wiley \& Sons, New York (1992).

11. Rob van der Pluijm, Out-of-Plane Bending of Masonry Behaviour and Strength, R. van der Pluijm (1999).

12. Satria, A. \& Imran, I., Peran Dinding Pengisi Terhadap Perubahan Perilaku Portal Terbuka Yang Diberi Beban Lateral Siklik, Tugas Akhir, ITB (1999).

13. Tambunan, S., Kajian Eksperimental dan Numerik Perilaku Dinding Pasangan Terkekang dengan Pembebanan Siklik, Tesis Magister, ITB (2001). 